\title{
Palavras da diretora
}

Este número da $R A P$ dedica-se a diversos assuntos, que acompanham a agenda das principais temáticas contemporâneas e prospectivas da gestão: internacionalização de empresas brasileiras como estratégia de desenvolvimento; o gestor como responsável pela integração organizacional; comportamento empreendedor; modelos de racionalidade visando o ecodesenvolvimento; capacitação e desenvolvimento contínuo de pessoas; gestão dos institutos públicos de pesquisa.

Internacionalização de empresas como política de desenvolvimento: uma abordagem de diplomacia triangular introduz abordagem analítica da inserção do Brasil no contexto internacional contemporâneo, com base na literatura de economia política e de negócios internacionais, que transcende as tradicionais avaliações de política internacional por contemplar relações envolvendo atores estatais e nãoestatais. A autora sugere, ainda, que o governo brasileiro adote a internacionalização de empresas brasileiras como estratégia de desenvolvimento.

Contradições gerenciais na disseminação da "cultura corporativa": o caso de uma estatal brasileira discute o papel do gestor ao atuar na integração organizacional. Os autores desenvolvem uma crítica às propostas integrativas de cultura e analisam dilemas e ambigüidades que podem evidenciar as contradições na atuação cotidiana dos gestores. A discussão é embasada empiricamente pela análise de um estudo de caso em uma regional da Empresa Brasileira de Cor-reios e Telégrafos. Para os autores, o gestor não é apenas elemento consensual, pois ele dissemina a integração, a diferenciação e a fragmentação, permeado por objetivos e questões pessoais, sociais e organizacionais, não se limitando aos interesses da empresa.

Tecendo uma virtuosa "colcha de retalhos": a constituição e interpretação de um corpus lingüístico num estudo sobre reflexividade e articulação empreendedora representa etapa fundamental de um processo investigativo que envolve a constituição e análise interpretativa de um corpus lingüístico capaz de propiciar avanço na direção apontada em etapa prévia de um estudo sobre reflexividade e articulação empreendedora.

Em busca de uma racionalidade convergente ao ecodesenvolvimento: um estudo exploratório de projetos de turismo sustentável e de responsabilidade social empresarial analisa processos de tomada de decisão organizacional que tentam superar o

RAP Rio de Janeiro 40(3):333-4, Maio/Jun. 2006 
modelo de racionalidade utilitarista econômica e incorporar outros modos de racionalidade, buscando promover o ecodesenvolvimento.

Compreendendo as iniciativas de educação a distância via internet: estudo de caso em duas grandes empresas no Brasil analisa o funcionamento e as características das iniciativas de educação a distância em grandes empresas no Brasil. Os resultados da pesquisa ajudam a compreender alguns aspectos fundamentais, tais como concepção educacional, público-alvo, financiamento, desenvolvimento dos cursos, avaliação, custos iniciais, retorno sobre o investimento, vantagens e desvantagens.

Metodologia para gerenciar projetos de pesquisa e desenvolvimento com foco em produtos: uma proposta relata a experiência do Instituto de Tecnologia em Fármacos (Far-Manguinhos), unidade da Fundação Oswaldo Cruz. O foco do trabalho é uma metodologia de gestão de projetos de $\mathrm{P} \& \mathrm{D}$, baseada no direcionamento dos projetos de pesquisa para obtenção de produtos e que considera suas características multidisciplinares e interdisciplinares e a incerteza inerente a este processo.

Boa leitura!

Deborah Moraes Zouain

Diretora e Editora da $R A P$ 